\author{
RESEARCH ARTICLE \\ 10.1029/2019JC016007 \\ Key Points: \\ - A sediment-derived tracer was \\ incorporated into a circulation \\ model of the Chukchi Sea to \\ investigate trends in benthic inputs \\ - The model results compare \\ favorably to water column \\ observations of radium-228, an \\ isotope naturally released from \\ sediments \\ - Benthic tracer inputs are highest \\ during early winter in the southern \\ Chukchi Sea and in late winter-early \\ spring in the central Chukch
}

Supporting Information:

- Supporting Information S1

Correspondence to:

L. E. Kipp,

lkipp@dal.ca

Citation:

Kipp, L. E., Spall, M. A., Pickart, R. S., Kadko, D. C., Moore, W. S., Dabrowski, J. S., \& Charette, M. A. (2020)

Observational and modeling evidence of seasonal trends in sediment-derived material inputs to the Chukchi Sea. Journal of Geophysical Research: Oceans, 125, e2019JC016007. https:// doi.org/10.1029/2019JC016007

Received 24 DEC 2019 Accepted 17 APR 2020 Accepted article online 27 APR 2020

(C)2020. American Geophysical Union. All Rights Reserved.

\section{Observational and Modeling Evidence of Seasonal Trends in Sediment-Derived Material Inputs to the Chukchi Sea}

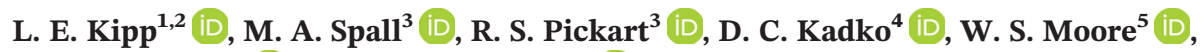 \\ J. S. Dabrowski ${ }^{2}$ iD, and M. A. Charette $^{2}$ iD \\ ${ }^{1}$ Ocean Frontier Institute, Dalhousie University, Halifax, Nova Scotia, Canada, ${ }^{2}$ Department of Marine Chemistry and \\ Geochemistry, Woods Hole Oceanographic Institution, Woods Hole, MA, USA, ${ }^{3}$ Department of Physical Oceanography, \\ Woods Hole Oceanographic Institution, Woods Hole, MA, USA, ${ }^{4}$ Florida International University, Applied Research \\ Center, Miami, FL, USA, ${ }^{5}$ Department of Earth and Ocean Sciences, University of South Carolina, Columbia, SC, USA
}

\begin{abstract}
Benthic inputs of nutrients help support primary production in the Chukchi Sea and produce nutrient-rich water masses that ventilate the halocline of the western Arctic Ocean. However, the complex biological and redox cycling of nutrients and trace metals make it difficult to directly monitor their benthic fluxes. In this study, we use radium-228, which is a soluble radionuclide produced in sediments, and a numerical model of an inert, generic sediment-derived tracer to study variability in sediment inputs to the Chukchi Sea. The ${ }^{228} \mathrm{Ra}$ observations and modeling results are in general agreement and provide evidence of strong benthic inputs to the southern Chukchi Sea during the winter, while the northern shelf receives higher concentrations of sediment-sourced materials in the spring and summer due to continued sediment-water exchange as the water mass traverses the shelf. The highest tracer concentrations are observed near the shelfbreak and southeast of Hanna Shoal, a region known for high biological productivity and enhanced benthic biomass.
\end{abstract}

Plain Language Summary Continental shelf sediments serve as a source of elements, such as carbon and nitrogen, that are important for sustaining life in the ocean. In the shallow Chukchi Sea north of Bering Strait, winter ice cover makes it difficult to collect year-round measurements that would improve our understanding of the shelf source of these elements. Instead, we use a naturally occurring radioactive tracer (radium-228) and a computer model to predict seasonal and spatial trends in the transport of elements from shelf sediments into the overlying Chukchi Sea. Our results suggest an enhanced release of sediment-derived materials to the southern Chukchi Sea during the winter, when there is increased water column mixing due to ice formation. Higher concentrations of the sediment-derived tracers were observed in the northern Chukchi Sea during the spring, likely due to continued additions from sediments as water moved northward over the shelf.

\section{Introduction}

Continental shelves make up over half the area of the Arctic Ocean (Jakobsson, 2002), where shelf sediments serve as important sources of carbon, nutrients, and trace metals to the upper water column (Anderson et al., 2017; Brown et al., 2016; Nakayama et al., 2011; Vieira et al., 2018). Rising air and water temperatures in the Arctic are diminishing ice cover over shelves, leading to increased exchange between the water column and shallow shelf sediments through enhanced vertical mixing and coastal erosion (Rainville \& Woodgate, 2009; Serreze et al., 2007; Williams \& Carmack, 2015; Woodgate, 2018). This amplified nutrient supply from sediments, along with reduced light limitation, can fuel increased primary production (Ardyna et al., 2014; Arrigo et al., 2008).

The Chukchi Sea is a region of high biological productivity (Grebmeier et al., 2015), though the timing and location of phytoplankton blooms are strongly influenced by water mass composition and circulation (Arrigo et al., 2017; Lowry et al., 2015, 2018). Primary production is limited by nitrogen, which is supplied through high nitrate concentrations in the Bering Strait inflow and by remineralization of organic matter over the Chukchi shelf (Codispoti et al., 2005; Lowry et al., 2015). Chukchi Winter Water (WW) is rich in these nutrient sources due to contact with sediments during transport over the shelf (Granger et al., 2018; Jones \& Anderson, 1986). WW is formed through brine rejection and convective mixing during ice 


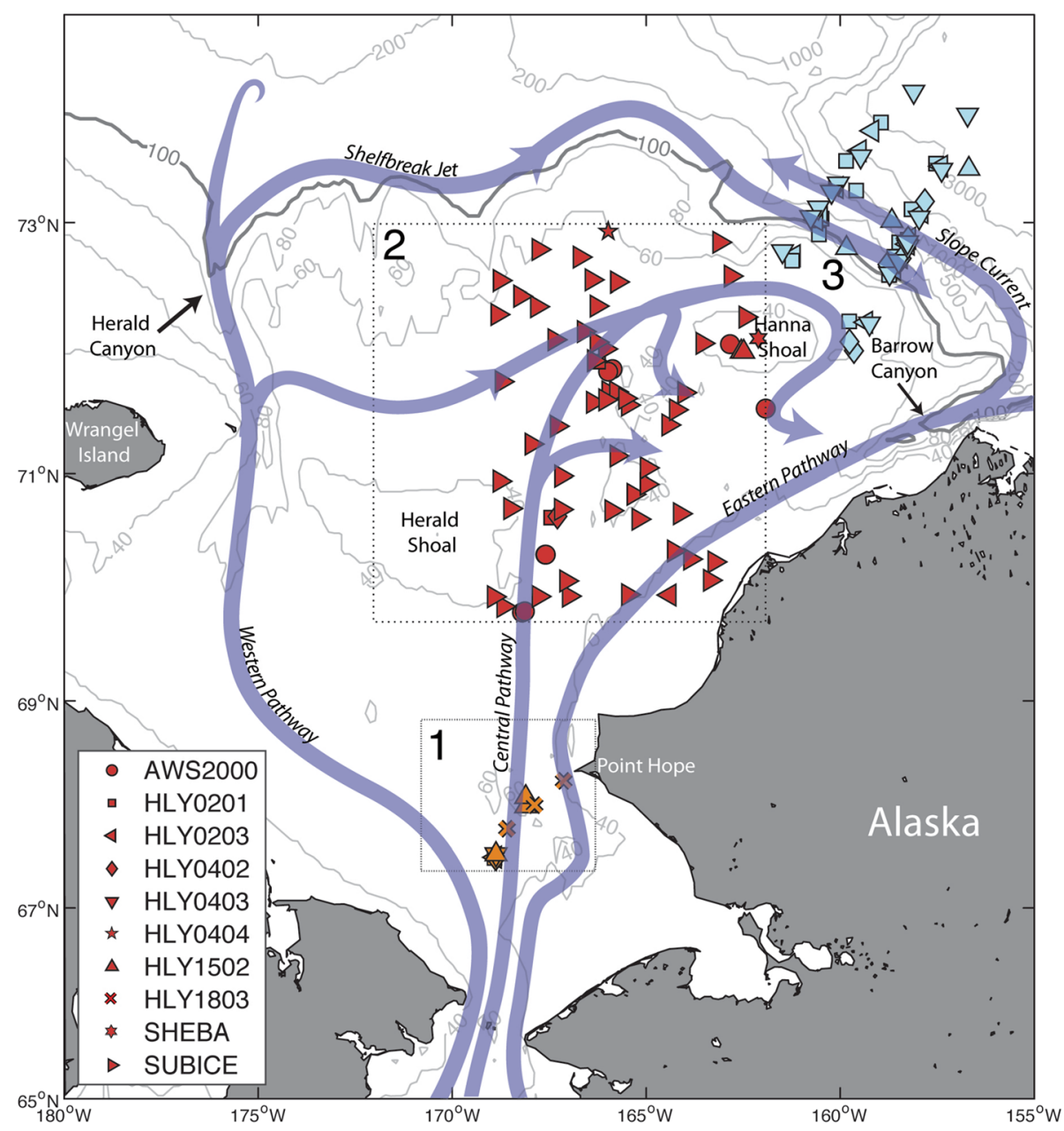

Figure 1. Map of the Chukchi Sea, indicating the locations of the ${ }^{228}$ Ra measurements used in the study. Locations included in the Point Hope domain are shown in orange (1); those included in the central shelf domain are shown in red (2); and those used to create the mean shelfbreak/slope sections of Figure 3 are shown in blue (3). Arrows indicate the general circulation features after Corlett and Pickart (2017). Boxes indicate the approximate bounds of the model domains used for the Point Hope and central shelf regions in Figure 2.

formation and lead refreezing (Muench et al., 1988; Pacini et al., 2019; Pickart et al., 2016; Weingartner et al., 1998). This cold and dense water mass serves as the primary source of nitrogen for phytoplankton in the Chukchi Sea (Arrigo et al., 2017; Lowry et al., 2015, 2018; Pacini et al., 2019; Pickart et al., 2016) and can ultimately be transported to the Canada Basin halocline via advection through Herald and Barrow Canyons.

Water masses over the Chukchi Shelf are transported via three main bathymetrically steered pathways (Lin et al., 2019; Pickart et al., 2016; Weingartner et al., 2005; Figure 1). The western pathway flows between Wrangel Island and Herald Shoal and leaves the shelf through Herald Canyon. The central pathway progresses northward between Herald and Hanna Shoals, joining some water that has passed through Herald Canyon, is steered eastward around Hanna Shoal, and ultimately flows through Barrow Canyon. The eastern pathway follows the Alaskan coast and combines with the central pathway in Barrow Canyon. Water exiting Herald Canyon is directed to the east and forms the Chukchi shelfbreak jet (Corlett \& Pickart, 2017; Li et al., 2019; Linders et al., 2017). This pathway spawns eddies that exchange materials with the Canada Basin (Mathis et al., 2007; Pickart et al., 2005; Spall et al., 2008). The water exiting Barrow Canyon feeds the Beaufort shelfbreak jet to the east and the Chukchi slope current to the west (Corlett \& Pickart, 2017; Li et al., 2019; Spall et al., 2018). Although the ultimate fate of the slope current is an area 
Table 1

Sources of ${ }^{228}$ Ra Data Compiled for This Study

\begin{tabular}{|c|c|c|c|c|c|c|}
\hline Sampling program/study name & Cruise identifier/abbreviation & Ship & Year & Dates & Season & Reference \\
\hline $\begin{array}{l}\text { Surface Heat Budget of } \\
\text { the Arctic Ocean }\end{array}$ & SHEBA & $\mathrm{n} / \mathrm{a}$ (ice camp) & 1998 & 27 and $28 \mathrm{Jun}^{\mathrm{a}}$ & Summer & Kipp et al., 2019 \\
\hline Arctic West Summer & AWS-2000 & USCGC Polar Star & 2000 & 5-10 Aug $^{\mathrm{a}}$ & Summer & Kipp et al., 2019 \\
\hline SBI & HLY0201 & USCGC Healy & 2002 & 6 May-14 Jun & Spring & $\begin{array}{l}\text { Kadko \& Muench, 2005; } \\
\text { Kipp et al., } 2019\end{array}$ \\
\hline SBI & HLY0203 & USCGC Healy & 2002 & 17 Jul-26 Aug & Summer & $\begin{array}{l}\text { Kadko et al., } 2008 \\
\text { Kipp et al., } 2019\end{array}$ \\
\hline SBI & HLY0402 & USCGC Healy & 2004 & 15 May-23 Jun & Spring & Kipp et al., 2019 \\
\hline SBI & HLY0403 & USCGC Healy & 2004 & 19 Jul-25 Aug & Summer & $\begin{array}{r}\text { Kadko et al., 2008; } \\
\text { Kipp et al., } 2019\end{array}$ \\
\hline SBI & HLY0404 & USCGC Healy & 2004 & 2 Sep-1 Oct & Fall & $\begin{array}{r}\text { Kadko et al., 2008; } \\
\text { Kipp et al., } 2019\end{array}$ \\
\hline $\begin{array}{l}\text { Study of Under Ice Blooms } \\
\text { in the Chukchi Ecosystem }\end{array}$ & SUBICE & USCGC Healy & 2014 & 13 May-24 Jun & Spring & Vieira et al., 2018 \\
\hline GEOTRACES & HLY1502 & USCGC Healy & 2015 & 6 Aug-10 Oct & Fall & $\begin{array}{l}\text { Kipp et al., 2018; } \\
\text { Kipp et al., } 2019\end{array}$ \\
\hline $\begin{array}{c}\text { AON: Western Arctic } \\
\text { Boundary Current }\end{array}$ & HLY1803 & USCGC Healy & 2018 & 25 Oct-18 Nov & Fall-Winter & Table S1 \\
\hline
\end{tabular}

Indicates specific collection dates of ${ }^{228} \mathrm{Ra}$ samples used here, expedition itself was longer.

of active research, modeling results (Spall et al., 2018) suggest that it may be an important transport pathway for materials delivered to the Beaufort Gyre.

The complicated biological and chemical cycling of nutrients, carbon, and trace metals makes it difficult to directly measure seasonal and long-term changes in the shelf source of these elements. However, naturally occurring radium-228 $\left({ }^{228} \mathrm{Ra} ; \mathrm{t}_{1 / 2}=5.75\right.$ years $)$ also has a sediment source and behaves relatively conservatively on timescales of upper ocean mixing. ${ }^{228} \mathrm{Ra}$ is produced by the decay of particle-bound ${ }^{232} \mathrm{Th}$ in sediments. Because it is more soluble than Th, Ra is released from sediment porewaters via diffusive processes and bioturbation or transported to the coastal ocean through rivers and submarine groundwater discharge (SGD). ${ }^{228} \mathrm{Ra}$ has been well established as a tracer of shelf inputs to the Arctic Ocean (Kadko et al., 2008; Kadko \& Muench, 2005; Kipp et al., 2018, 2019; Rutgers van der Loeff et al., 1995, 2012, 2018). The timescale for particle removal of Ra from surface ocean waters is on the order of hundreds of years (Moore \& Dymond, 1991; van Beek et al., 2007). Consequently, we expect negligible ${ }^{228} \mathrm{Ra}$ removal compared to loss through decay and dilution by mixing. ${ }^{228}$ Ra therefore serves as a useful quasi-conservative tracer of shelfand sediment-derived materials.

In this study, we combine observational and modeling approaches to elucidate spatial and temporal variability in the inputs of sediment-derived materials to the Chukchi Sea and Chukchi shelfbreak jet. First, we use a collection of ${ }^{228} \mathrm{Ra}$ data collected on multiple sampling expeditions to investigate the seasonal trends in ${ }^{228} \mathrm{Ra}$ activities over the Chukchi shelf and shelfbreak. We then describe the integration of an inert, generic sediment-derived tracer into a regional model of Chukchi Sea circulation and compare the modeled tracer concentrations to the observed signals in ${ }^{228} \mathrm{Ra}$ activities. The combination of these two approaches improves our understanding of the mechanisms driving sediment-derived material fluxes to the Chukchi Sea. Finally, we derive the flux of ${ }^{228}$ Ra from sediments on the southern Chukchi Shelf.

\section{Methods}

\subsection{Radium-228}

We compiled ${ }^{228}$ Ra measurements made over the Chukchi shelf and slope over the past two decades. Almost all of the data have been previously published (Table S1 in the supporting information), and the associated sampling and analysis methods can be found in the references listed in Table 1 and Table S1. Recently obtained ${ }^{228} \mathrm{Ra}$ data from a 2018 expedition (HLY1803) are also presented in Table S1. HLY1803 samples $(\sim 250$ L) were collected using Niskin bottles on a conductivity-temperature-depth (CTD) rosette, 
transferred to plastic barrels, filtered at $\sim 1 \mathrm{~L} \mathrm{~min}^{-1}$ through $\mathrm{MnO}_{2}$-coated acrylic fibers to quantitatively capture Ra (Reid et al., 1979), and analyzed using previously published methods (e.g., Kipp et al., 2018). Most of the samples used in this compilation were not prefiltered to remove particles (Kadko et al., 2008; Kadko \& Muench, 2005; Vieira et al., 2018) with the exception of the 2015 GEOTRACES samples, which were prefiltered through a $5 \mu \mathrm{m}$ Hytrex cartridge (Kipp et al., 2019). On the SUBICE, HLY1052, and HLY1803 cruises, the $\mathrm{MnO}_{2}$-coated fibers were rinsed with deionized water after collection to remove any particles on the fiber. The amount of ${ }^{228} \mathrm{Ra}$ on particles is small, $>2$ orders of magnitude below seawater activities (van Beek et al., 2007), so these small differences in sample collection should not bias the data comparison.

Multiple transects from the Western Arctic Shelf-Basin Interactions (SBI) program and the Arctic GEOTRACES expedition crossed the shelfbreak in similar locations northeast of Hanna Shoal and west of Barrow Canyon. These transects were divided by season (spring: May-June, summer: July-August, fall: September-October). Seasonal composite vertical sections of ${ }^{228} \mathrm{Ra}$ and hydrographic properties were created using Laplacian-Spline interpolation, following the approach described in Corlett and Pickart (2017).

\subsection{Chukchi Sea Numerical Model}

The regional circulation model used in this study has been previously described (Spall, 2007; Spall et al., 2018) and is only briefly summarized here. It is a version of the MIT general circulation model (Marshall et al., 1997) coupled to a sea ice model and forced with surface fluxes of heat, freshwater, and momentum derived from the daily North American Regional Reanalysis product (www.esrl.noaa.gov/psd/data/ gridded/data.narr.html). The model was also forced by volume fluxes and the seasonally varying temperature and salinity characteristics of the inflowing water through Bering Strait, based on long-term measurement records from this region (Weingartner et al., 2005; Woodgate et al., 2005b).

The model domain was set on an $f$-plane with the Coriolis parameter $f=1.2 \times 10^{-4} \mathrm{~s}^{-1}$. The southwest corner of the grid is $63^{\circ} \mathrm{N}$ and $180^{\circ} \mathrm{W}$, and the domain extends $1,440 \mathrm{~km}$ to the east and $2,160 \mathrm{~km}$ to the north. The horizontal grid spacing was $5 \mathrm{~km}$, and the vertical grid was as follows: $5 \mathrm{~m}$ spacing in the upper $80 \mathrm{~m}$, $10 \mathrm{~m}$ spacing between 80 and $110 \mathrm{~m}, 20 \mathrm{~m}$ spacing between 110 and $150 \mathrm{~m}, 30 \mathrm{~m}$ spacing between 150 and $210 \mathrm{~m}$, and grid points at 250,300, 375, 475, 625, 800, and 1,000 m. Bottom topography down to 1,000 $\mathrm{m}$ was interpolated from the ETOPOv2 2-min gridded bathymetry (www.ngdc.noaa.gov/mgg/global/etopo2.html).

A generic tracer designed to represent benthic ${ }^{228} \mathrm{Ra}$ inputs was injected from the sediments north of Bering Strait. Radium transport from porewaters to the overlying water column occurs through diffusion, bioturbation, and sediment resuspension. However, in the Chukchi Sea, Vieira et al. (2018) found that sediment resuspension could account for $<10 \%$ of the benthic ${ }^{228} \mathrm{Ra}$ flux, thus diffusion and bioturbation must be the main mechanisms of ${ }^{228} \mathrm{Ra}$ transport into the water column. Fluxes of ${ }^{228} \mathrm{Ra}$ are higher from fine grained sediments compared to coarse sediments (Moore et al., 2008). Although sediment texture is quite variable in the northeast Chukchi Sea (e.g. 9-98\% silt + clay; Trefry et al., 2014), sediment variability does not appear to be the main control on ${ }^{228} \mathrm{Ra}$ activities in the overlying water column (Vieira et al., 2018; see their Figure S5). We therefore did not consider different sediment types in the model. This model was formulated to represent enhanced turbulent mixing during wintertime water column overturning and has a minimum background mixing term to represent ${ }^{228} \mathrm{Ra}$ input from sediments when the water column is stable.

The tracer flux is proportional to the amount of mixing at the bottom:

$$
F=1-e^{-\kappa / \kappa \max }
$$

where $F$ is the tracer flux, $\kappa$ is the vertical mixing coefficient at the bottom, and $\kappa_{\max }=0.1 \mathrm{~m}^{2} \mathrm{~s}^{-1}$. The vertical mixing coefficient was determined by the KPP parameterization (Large et al., 1994). The vertical mixing coefficient is calculated as

$$
\kappa=h w(\sigma) G(\sigma)
$$

where $h$ is the boundary layer thickness, $w$ is a turbulent velocity scale, $G$ is a shape function, and $\sigma$ is a nondimensional vertical coordinate equal to depth divided by $h$. The boundary layer thickness is defined as the depth at which a bulk Richardson number meets the critical value of 0.3 , where the Richardson number is a relative measure of stratification versus vertical shear of the horizontal velocity. Above this 

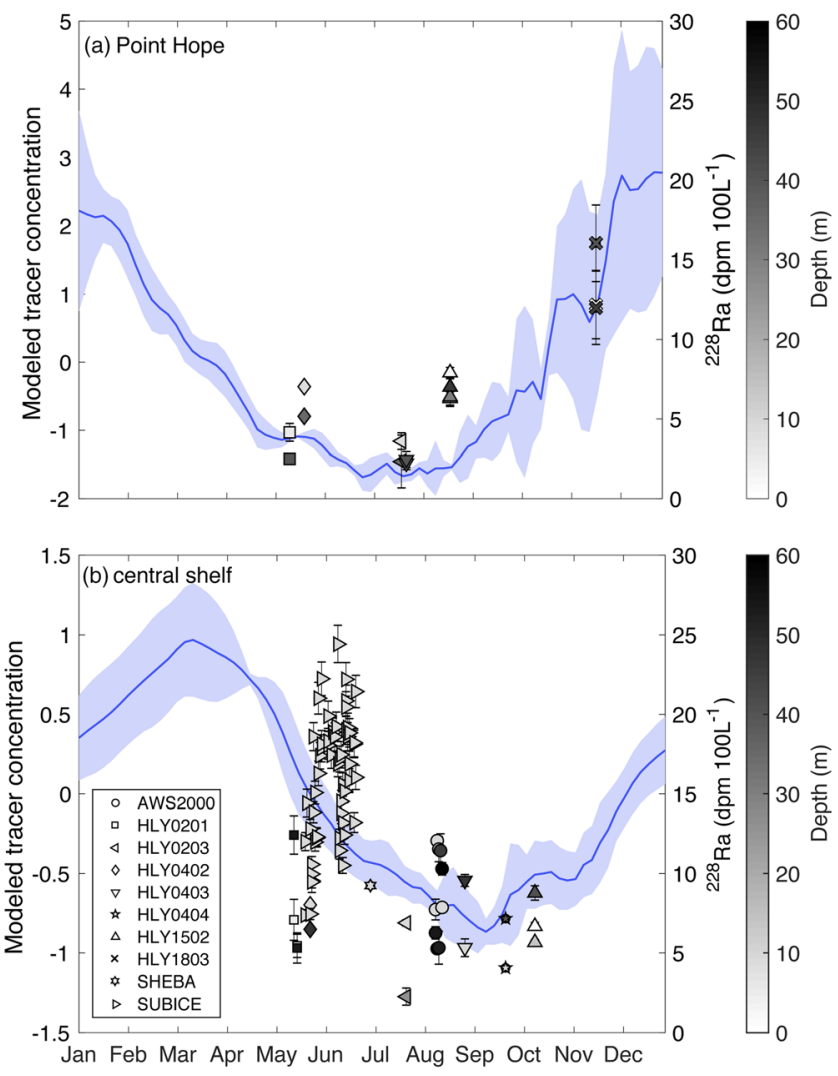

Figure 2. Seasonal changes in modeled tracer concentration (blue line; arbitrary units) and ${ }^{228}$ Ra activities (symbols; dpm $100 \mathrm{~L}^{-1}$ ) (a) near Point Hope and (b) over the central shelf. The modeled tracer concentration represents the average of the last 3 years of the model run, with the mean value subtracted to highlight the seasonal changes. The blue shading represents the standard deviation on the 3-year average. The modeled tracer concentration represents depth-averaged values, while symbol shading indicates discrete sample collection depths. value, turbulent mixing across density layers is suppressed. The turbulent velocity scale is proportional to a frictional velocity scale and a flux profile that depends on the strength of the surface buoyancy forcing, getting larger for stronger negative buoyancy flux. The shape function $G$ has a cubic form in the vertical. Details of the parameterization can be found in Large et al. (1994).

The tracer is represented in arbitrary units. This form for the flux of tracer into the water column reflects a strong dependence on the strength of vertical mixing at the bottom. If mixing is weak, it assumes that the tracer remains trapped near the sediment-water interface, but as mixing approaches and exceeds $0.1 \mathrm{~m}^{-2} \mathrm{~s}^{-1}$, the turbulence is sufficiently strong to drive the tracer from the benthic layer into the water column. The results are qualitatively insensitive to the specific choice of $x_{\max }$ provided that it is larger than is typically found for weakly sheared, stratified flows. We find that the flux of tracer into the water column is dominated by convective instability events during which the vertical mixing is very large. While other mixing parameterizations and flux formulations could be chosen, the important feature for our purposes is that the tracer is introduced into the water column when mixing near the bottom is strong. For the Chukchi Sea, strong mixing is triggered by convective instability, which would be represented in any reasonable mixing parameterization that considers surface buoyancy fluxes. A minimum background mixing coefficient of $10^{-5} \mathrm{~m}^{-2} \mathrm{~s}^{-1}$ was specified, representing ocean turbulent diffusion under stably stratified conditions.

The model was run for 4 years, and the mean of the tracer concentrations over the last 3 years of the run were used to assess seasonal trends. Model runs were forced with daily fields of atmospheric variables from January 2002 to December 2005 to facilitate comparison with the seasonal trends captured by the SBI cruises (2002-2004).

\section{Seasonal Trends in ${ }^{228} \mathrm{Ra}$ in the Chukchi Sea}

We focused our analysis on three areas of the eastern Chukchi Sea that had sufficient data coverage to facilitate seasonal comparisons: (1) southwest of Point Hope, Alaska $\left(\sim 68^{\circ} \mathrm{N}, 169^{\circ} \mathrm{W}\right.$; orange symbols in Figure 1); (2) the central shelf (defined as the area between $69^{\circ} \mathrm{N}$ and $73^{\circ} \mathrm{N}$ and west of $162^{\circ} \mathrm{W}$; red symbols in Figure 1); and (3) the shelfbreak/upper-slope northeast of Hanna Shoal (blue symbols in Figure 1). The ${ }^{228}$ Ra activities near Point Hope were higher in the winter (12-16 dpm $100 \mathrm{~L}^{-1}$ ) compared to the spring and summer (2-7 dpm $100 \mathrm{~L}^{-1}$; Figure 2a). The low spring and summer activities are similar to ${ }^{228} \mathrm{Ra}$ levels in Bering Strait at this time of year: the average ${ }^{228} \mathrm{Ra}$ activity in Bering Strait between May and August is $6.3 \pm 4.4 \mathrm{dpm} 100 \mathrm{~L}^{-1}$ (Kipp et al., 2019; Vieira et al., 2018; Table S1). The higher winter activities near Point Hope may therefore reflect an additional wintertime input of ${ }^{228} \mathrm{Ra}$ from the large sediment source north of Bering Strait. However, fall and winter measurements of ${ }^{228} \mathrm{Ra}$ in the Bering Sea and Strait are needed to rule out the possibility of a seasonal change in the ${ }^{228}$ Ra activities in the Bering Sea export (see section 5).

Over the central shelf, there were high ${ }^{228}$ Ra activities in the spring, when activities reached $20-25 \mathrm{dpm}$ $100 \mathrm{~L}^{-1}$, while lower activities around 5-10 dpm $100 \mathrm{~L}^{-1}$ were observed in the summer and fall (Figure 2b). It should be noted, however, that all of the ${ }^{228} \mathrm{Ra}$ activities $>15 \mathrm{dpm} 100 \mathrm{~L}^{-1}$ were observed on a single expedition (SUBICE) that took place during late spring; thus, more data are needed to determine whether these activities are typical. At the time of the SUBICE sampling, there was active water column convection due to lead refreezing (Lowry et al., 2018; Pacini et al., 2019; Vieira et al., 2018), which likely contributed to the high ${ }^{228} \mathrm{Ra}$ levels. 

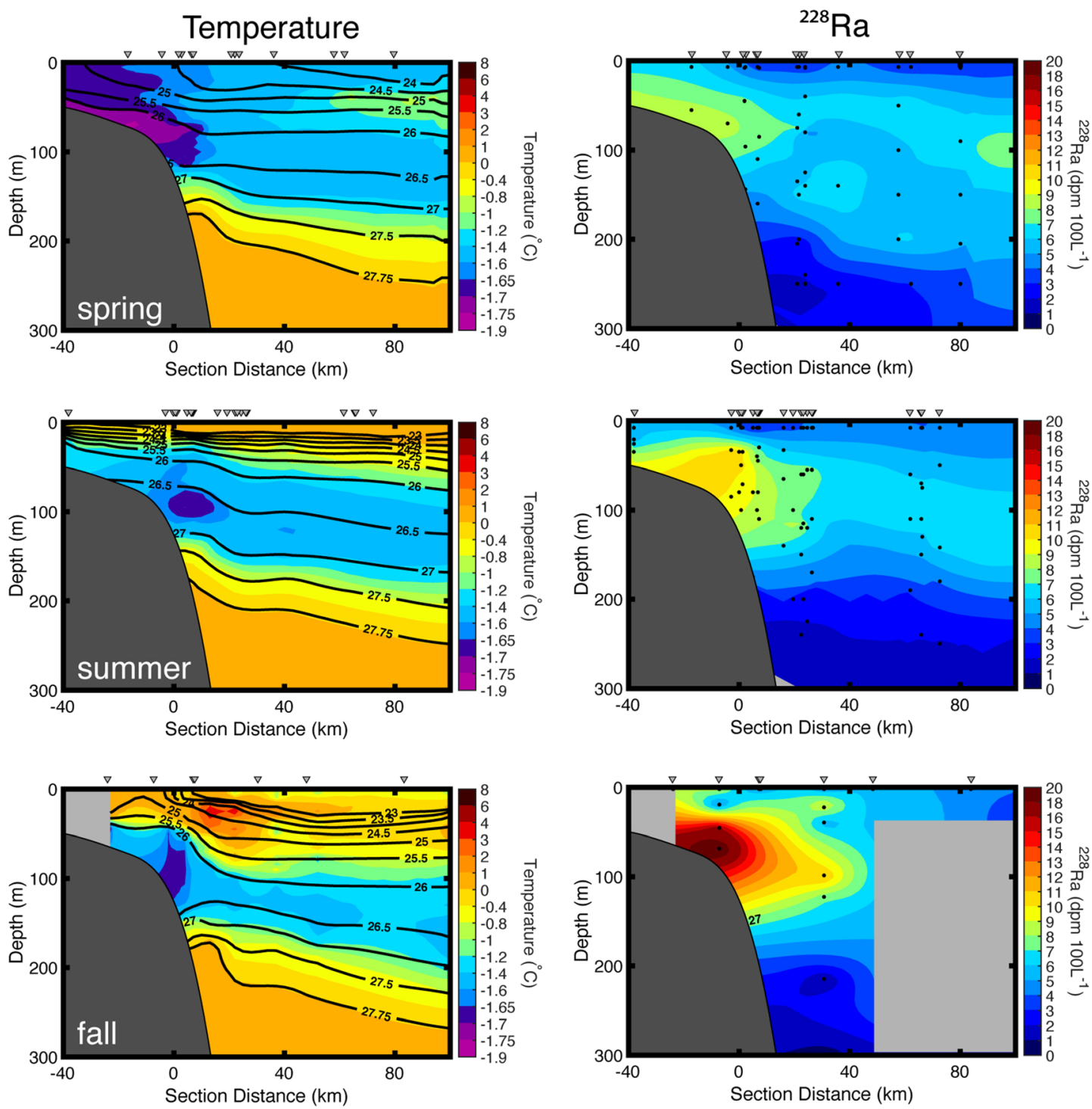

Figure 3. Seasonally averaged mean vertical sections. Each row corresponds to a season (spring: May-June, $n=3$; summer: July-August, $n=4$; fall: SeptemberOctober, $n=1$ ), and the columns correspond to potential temperature and ${ }^{228} \mathrm{Ra}$ activities (color) overlain by potential density (contours, $\mathrm{kg} \mathrm{m}^{-3}$ ). Station locations are denoted by the gray inverted triangles above each plot; the hydrographic variables were measured every meter, while black dots indicate the ${ }^{228} \mathrm{Ra}$ sample depths.

To assess seasonality at the shelfbreak, composite mean vertical sections of potential temperature, potential density, and ${ }^{228} \mathrm{Ra}$ activities were constructed (Figure 3). These indicate that the highest ${ }^{228} \mathrm{Ra}$ activities were associated with cold WW flowing eastward in the shelfbreak jet and along the outer shelf (Corlett \& Pickart, 2017; Li et al., 2019; Pickart et al., 2005). Interestingly, the seasonal trend in the ${ }^{228} \mathrm{Ra}$ activities near the shelfbreak is opposite to the seasonal trend in WW presence: the ${ }^{228} \mathrm{Ra}$ activities increased from spring (7-8 dpm $\left.100 \mathrm{~L}^{-1}\right)$ to summer (10-12 dpm $\left.100 \mathrm{~L}^{-1}\right)$ to fall $\left(15-20 \mathrm{dpm} 100 \mathrm{~L}^{-1}\right)$, while the WW presence decreased over this time period. We note, however, that the composite vertical section for the fall is only based on HLY1502 data, so we cannot rule out variability due to interannual differences or sampling resolution.

\section{Modeled Sediment-Derived Tracer Distributions}

The numerical model was able to reproduce the main circulation features and seasonal variability in temperature, salinity, and ice coverage in the Chukchi Sea (Spall, 2007). The concentration of the 

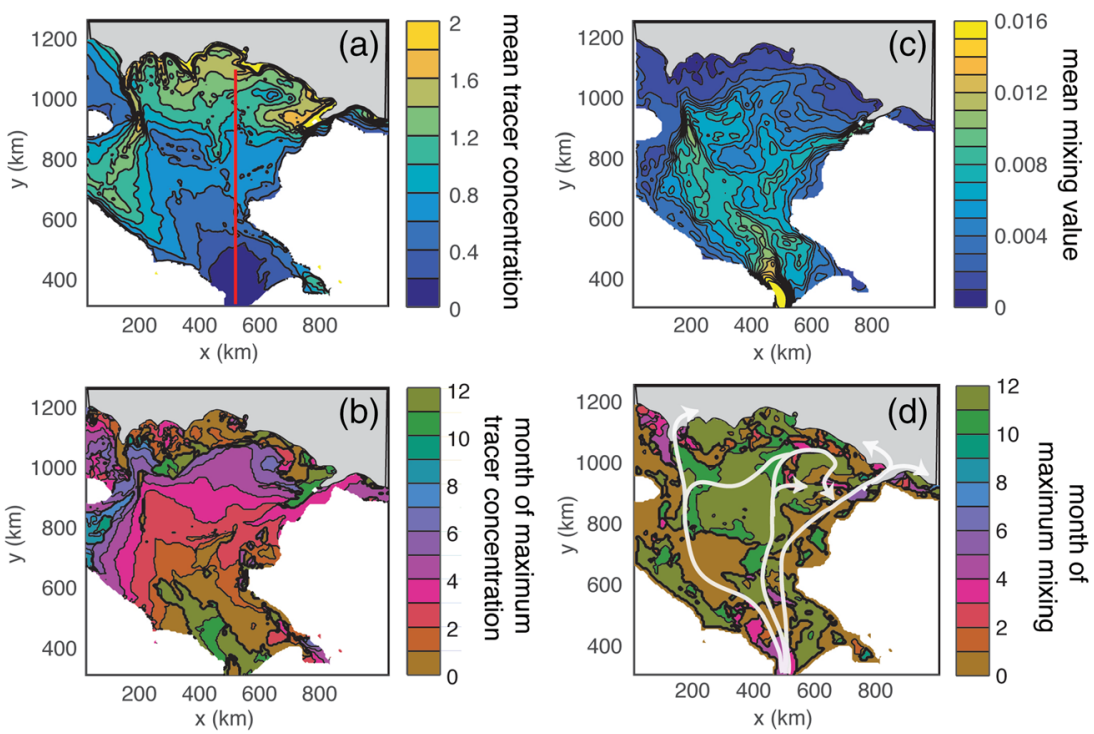

Figure 4. Modeled (a) mean depth-averaged tracer concentration (arbitrary units), (b) month of maximum depth-averaged tracer concentration, (c) mean depth-averaged mixing values $\left(\mathrm{m}^{2} \mathrm{~s}^{-1}\right)$, and (d) month of maximum mixing. Mean values are based on the last 3 years of the model run. Areas above sea level are white, and areas deeper than $100 \mathrm{~m}$ are gray. The red line on panel (a) indicates the location of the section in Figure 5. White arrows on (d) indicate the general circulation pathways from Figure 1.

depth-averaged sediment tracer generally increased northward from Bering Strait and was high near the shelfbreak (Figures 4a and 5a). The highest tracer concentrations over the shelf were observed southeast of Hanna Shoal. This result is consistent with observations of high nitrate concentrations (Lin et al., 2019; Lowry et al., 2015) and enhanced benthic biomass and biological productivity (Grebmeier et al., 2015) in this region of the Chukchi shelf. The timing of peak tracer concentrations over the shelf also showed a latitudinal trend: the highest tracer concentrations were observed in the winter over the southern shelf and in the spring over the central shelf. This is seen in Figure $4 \mathrm{~b}$ and by the diagonal trend in tracer concentration in Figure 5a.

Tracer concentrations at the surface were more seasonally variable than the depth-averaged concentrations and did not reflect the year-round high concentrations near the shelfbreak that were apparent in the depth-integrated concentrations (compare Figures 5a and 5b). Tracer concentrations at the surface are more indicative of depth averaged tracer concentrations during the winter and spring, compared to summer when the stratification is stronger. The magnitude of the seasonal changes in surface tracer concentration also increased with latitude.
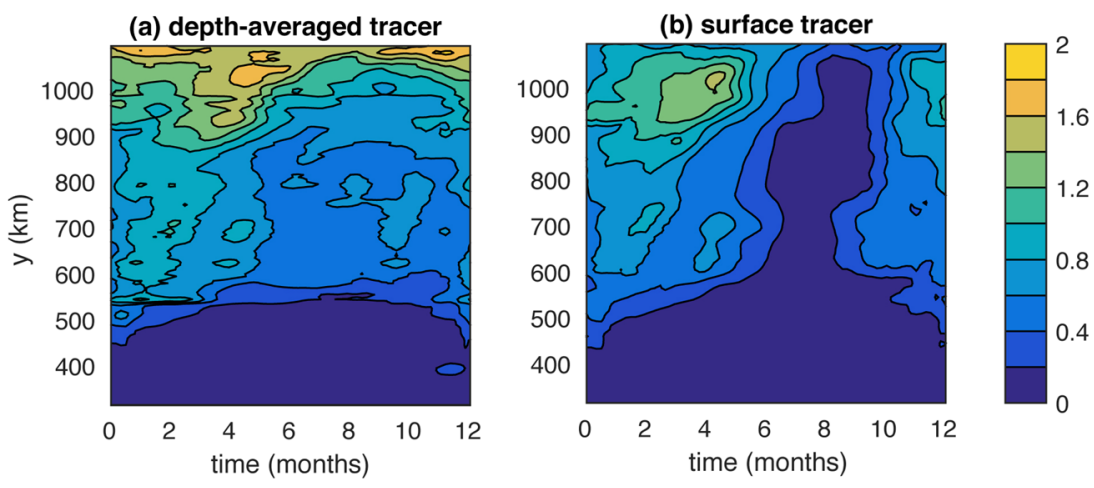

Figure 5. (a) Depth-averaged and (b) surface tracer concentrations (in arbitrary units) as a function of time and distance along a meridional line from Bering Strait to the Chukchi shelfbreak. The location of the line is shown in Figure 4a. 

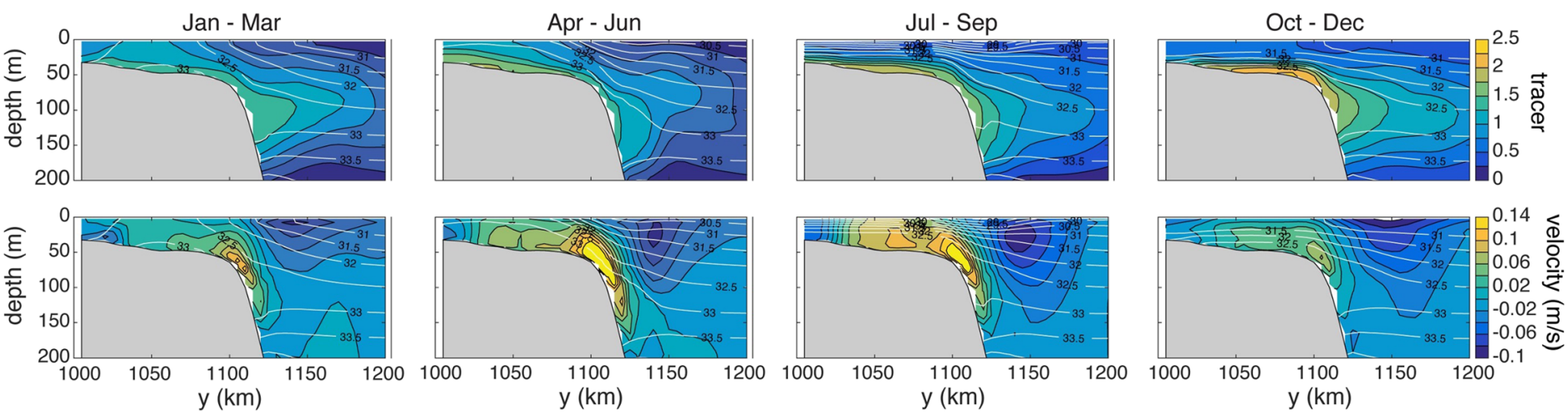

Figure 6. Seasonally averaged vertical sections from the model at the shelfbreak northeast of Hanna Shoal. The top row shows tracer concentrations (color, arbitrary units) overlain by salinity (contours). The bottom row shows velocity (color, $\mathrm{m} \mathrm{s}^{-1}$ ) overlain by salinity (contours). Positive velocities are eastward.

Each panel represents a 3-month average.

The modeled magnitude of mean depth-averaged water column mixing was strongest just north of Bering Strait and in Herald and Barrow Canyons (Figure 4c). There is also a signature of enhanced mixing along the three major flow pathways emanating from Bering Strait. In the northern part of the shelf, the mixing was generally weaker, likely due to stronger stratification there. The magnitude of water column mixing was largest over most of the Chukchi shelf in the winter (November-January, Figure 4d); this is consistent with brine rejection and convective overturning during ice formation at this time of year.

To facilitate a comparison with the available ${ }^{228} \mathrm{Ra}$ data, we examined seasonal changes in depth-averaged tracer concentrations in parts of the model domain corresponding to the three shelf areas from Figure 1. Near Point Hope, the peak in the modeled tracer concentrations coincided with winter mixing in November-January, and minimum concentrations are observed in June and July (Figure 2a). Mixing during the winter enhances flux of the tracer into the water column, and the summer decrease in tracer concentrations is likely due to the advective removal of the tracer-enriched water mass northward. The available ${ }^{228} \mathrm{Ra}$ measurements near Point Hope agree with the model: the activities recorded during the summer were some of the lowest observed in the Chukchi Sea, while higher activities were observed in November.

Over the central shelf, the peak in modeled tracer concentration occurred slightly later in the year, around March (Figure 2b). This seasonal shift reflects continued tracer addition from the sediment as the WW advects northward from Point Hope. Similar to the modeled tracer concentrations, the observed ${ }^{228} \mathrm{Ra}$ activities over the central shelf were highest in the spring and decreased through the summer and fall. The phase difference in temporal trends observed in the Point Hope and central shelf domains are consistent with the broad spatial trends on the shelf (Figure $4 \mathrm{~b}$ ). The largest offset between the data and model occurs in the spring over the central shelf. This may be due in part to spatial variability captured in the discrete ${ }^{228} \mathrm{Ra}$ activities, while the model represents the average tracer concentration over the entire area.

At the shelfbreak northeast of Hanna Shoal, the model tracer concentrations increased throughout the year and were highest in early winter (Figure 6, top row). This is consistent with the observed trend in the ${ }^{228} \mathrm{Ra}$ activities, which increased from spring through summer and into the fall (there are no wintertime observations of ${ }^{228} \mathrm{Ra}$ available for comparison; Figure 3). The eastward flowing shelfbreak jet and westward flowing slope current in the model were both strongest in the warm months of the year and weaker in the cold months of the year (Figure 6, bottom row); this trend is generally consistent with observations (Li et al., 2019). Both of these pathways facilitate the transport of shelf-derived materials into the interior basin (Pickart et al., 2005; Spall et al., 2018). The seasonal offset between the peak tracer concentrations over the shelf in the spring and in the shelfbreak jet in the fall reflects the time it takes for water to be transported off the shelf through the western advective pathway discussed above; this transit time is consistent with previously suggested water residence times of roughly 3-6 months in the Chukchi Sea (Pickart et al., 2016; Spall, 2007; Weingartner et al., 1998; Woodgate et al., 2005a). 


\section{Mechanisms Driving Seasonal and Latitudinal Changes in Sediment Inputs}

The compilation of ${ }^{228} \mathrm{Ra}$ measurements and modeled tracer concentrations presented in this study shows that there is an accumulation of ${ }^{228} \mathrm{Ra}$ in WW over the course of the year and indicates a seasonal cycle in the export of this sediment-derived tracer from the Chukchi shelf. The seasonal changes in ${ }^{228}$ Ra are likely due to a combination of water column overturning and contact time with shelf sediments. Storms during the fall can increase vertical mixing (Ardyna et al., 2014), and WW formation causes water column overturning (Muench et al., 1988; Pacini et al., 2019; Pickart et al., 2016; Weingartner et al., 1998). Freeze-up (and thus WW formation) progresses from north to south, typically taking several weeks to a month for ice to cover the entire shelf (Frey et al., 2015). The resulting convection induces exchange of ${ }^{228} \mathrm{Ra}$ from the benthic boundary layer into the overlying water column; thus, we would expect to observe the highest ${ }^{228} \mathrm{Ra}$ activities and modeled tracer concentrations during the winter. The winter maximum in the modeled mixing supports the idea that this convection occurs across the majority of the shelf between November and January. However, the maximum ${ }^{228} \mathrm{Ra}$ activities and modeled tracer concentrations are temporally and spatially variable. The maximum occurs earlier in the winter over the southern shelf and in the spring-summer over the northern shelf. This is likely due to the continued addition of sediment-derived materials during the transit of WW across the Chukchi Sea. WW formed farther south will spend more time in contact with shelf sediments during its northward transport across the shelf and eventually to the shelfbreak jet. The water reaching the shelfbreak in the fall and winter (which was farther south at the time of ice formation) would therefore have a longer contact time with shelf sediments, during which time it could become more enriched in ${ }^{228} \mathrm{Ra}$ and other shelf-sourced elements than the water reaching the shelfbreak in the spring (which was farther north during ice formation and spent less time over the shelf). The northward increase in the modeled depth-averaged tracer concentrations reflects this cumulative enrichment.

Coastal sources including rivers, SGD, and coastal erosion can also affect ${ }^{228}$ Ra activities in the Chukchi Sea but are not included in the model. While no large Arctic rivers discharge directly into the Chukchi Sea, the Yukon River enters the Bering Sea, and some of this riverine material is transported through Bering Strait. ${ }^{228} \mathrm{Ra}$ activities in the Yukon vary between 8 and $25 \mathrm{dpm} 100 \mathrm{~L}^{-1}$, and the riverine flux of ${ }^{228} \mathrm{Ra}$ to the coastal ocean $\left({ }^{228} \mathrm{Ra}\right.$ activity multiplied by water discharge rate) is highest between June and October due to the high water volumes discharged during the summer (Kipp et al., 2020). This does not coincide with the pattern of ${ }^{228} \mathrm{Ra}$ activities observed over the shelf (Figure 2), indicating that riverine influence is not a main control on the seasonal change in ${ }^{228}$ Ra activities. While little is known about SGD in this region, permafrost is thought to act as a physical barrier to discharge (Cochand et al., 2019; Walvoord et al., 2012). SGD is therefore more likely to be a source of ${ }^{228} \mathrm{Ra}$ to the Chukchi Sea during the summer, when the active (seasonally frozen) layer has thawed and is more permeable. Similarly, coastal erosion, which can serve as a ${ }^{228}$ Ra source through sediment desorption in high ionic strength seawater, occurs during the summer due to a combination of thermal (thawing permafrost) and mechanical (increased wave action during open water season) erosion (Günther et al., 2015; Jones et al., 2009). The riverine, SGD, and erosional sources of ${ }^{228} \mathrm{Ra}$ to the shelf are thus all highest in the summer, and while these coastal sources may contribute to higher ${ }^{228} \mathrm{Ra}$ activities near Alaska, they cannot account for the observed seasonal trends in the Chukchi Sea. Further, the magnitude of the ${ }^{228} \mathrm{Ra}$ inputs from these sources is much smaller than that from sediments; an Arctic-wide mass balanced showed that shelves contribute over $80 \%$ of ${ }^{228} \mathrm{Ra}$ to Arctic surface waters (Kipp et al., 2018).

Another possible influence on the seasonal cycle of ${ }^{228} \mathrm{Ra}$ in the Chukchi Sea is a seasonal change in ${ }^{228} \mathrm{Ra}$ activities in the Bering Sea, which can be propagated through Bering Strait. WW formation can occur in the northern Bering Sea (Muench et al., 1988) and will likely result in ${ }^{228}$ Ra enrichment through the same mechanisms we propose for the Chukchi Sea. This cold, dense water mass is transported through the Bering Strait between January and April (Woodgate et al., 2005a). Lacking wintertime ${ }^{228} \mathrm{Ra}$ data from the Bering Strait, it is difficult to constrain this ${ }^{228} \mathrm{Ra}$ source, and we cannot rule out the possibility that the high activities observed in the central Chukchi during the spring may be due in part to this Bering Sea inflow. However, it is known that WW is further transformed in the Chukchi Sea through the refreezing of leads and polynyas (Pacini et al., 2019). Therefore, regardless of the ${ }^{228}$ Ra activities in the Bering Strait inflow, the physical mechanisms we outline here for ${ }^{228} \mathrm{Ra}$ enrichment over the Chukchi Shelf remain valid. Further, the model only accounts for ${ }^{228} \mathrm{Ra}$ inputs from sediments north of Bering Strait, with no tracer 

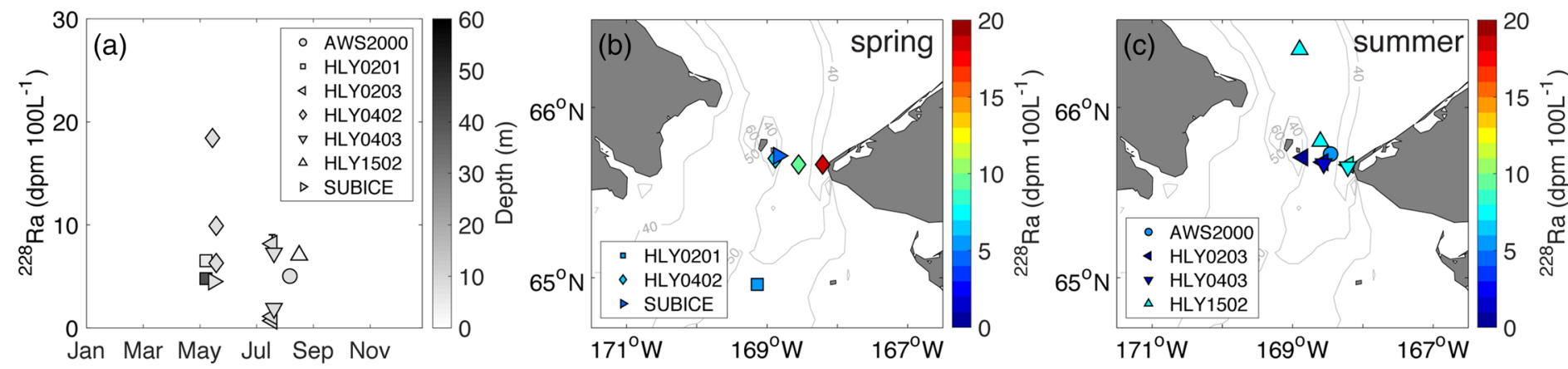

Figure 7. Seasonal changes in ${ }^{228} \mathrm{Ra}$ inflow through Bering Strait. (a) Radium-228 activities measured in Bering Strait as a function of collection month, shaded by collection depth. (b) Spring (May-June) and (c) summer (July-August) maps of ${ }^{228}$ Ra activities in Bering Strait. When more than one sample was collected at a station, the activities shown in panels (b) and (c) are the average of all sample depths.

inflow through the strait. The model output therefore indicates that a seasonal cycle in sediment-derived materials in the Chukchi Sea is to be expected regardless of changes in the Bering Strait inflow.

\section{Benthic Flux of ${ }^{228}$ Ra}

Primary production in the Chukchi Sea is limited by nitrogen, and shelf sediments provide an important source of nutrients, including ammonium $\left(\mathrm{NH}_{4}^{+}\right.$), to overlying waters (Brown et al., 2015; Devol et al., 1997; Henriksen et al., 1990; Mathis et al., 2014). Because they share a sediment source, ${ }^{228}$ Ra provides a useful tool for quantifying benthic nutrient inputs. Here, we calculate the ${ }^{228} \mathrm{Ra}$ flux from sediments near Point Hope, where the benthic and advective inputs of ${ }^{228} \mathrm{Ra}$ can be separated by constraining Bering Strait inflow.

Assuming that the system is in steady state over a 3-month period (the lower end of water residence time estimates for the Chukchi Shelf; Weingartner et al., 1998; Woodgate et al., 2005a; Spall, 2007; Pickart et al., 2016), the input of ${ }^{228} \mathrm{Ra}$ from sediments $\left(\mathrm{J}_{\text {sed }}\right.$; atoms $\left.\mathrm{m}^{-2} \mathrm{~d}^{-1}\right)$ is balanced by the loss to radioactive decay and advection:

$$
\mathrm{J}_{\mathrm{sed}}=\left(\lambda \mathrm{C}_{\mathrm{PH}}+\mathrm{k}\left(\mathrm{C}_{\mathrm{PH}}-\mathrm{C}_{\mathrm{BS}}\right)\right) * \mathrm{z}_{\mathrm{PH}},
$$

where $\lambda$ is the decay rate of ${ }^{228} \mathrm{Ra}\left(3.30 \times 10^{-4} \mathrm{~d}^{-1}\right), \mathrm{C}_{\mathrm{PH}}$ and $\mathrm{C}_{\mathrm{BS}}$ are the average ${ }^{228} \mathrm{Ra}$ concentrations (atoms $\mathrm{m}^{-3}$ ) in the water column near Point Hope and in the Bering Strait, respectively, $\mathrm{k}$ is the water exchange rate $\left(0.011 \mathrm{~d}^{-1}\right)$, and $\mathrm{z}_{\mathrm{PH}}$ is the average water column depth $(50 \mathrm{~m}$; estimated from the bathymetry of the Point Hope domain shown in Figure 1). The ${ }^{228} \mathrm{Ra}$ concentration in the Bering Strait is subtracted from the Point Hope average to determine the net effect of ${ }^{228} \mathrm{Ra}$ inputs to the Point Hope area. For this calculation, we assume that the ${ }^{228} \mathrm{Ra}$ concentration in the Bering Strait is constant based on the data available from spring and summer (Figure 7; Kipp et al., 2019; Vieira et al., 2018), but this estimate should be improved with fall and winter measurements as discussed above (see section 5). Because the residence time of the water over the shelf is much shorter than the decay rate of ${ }^{228} \mathrm{Ra}$, the decay term is negligible, and equation 2 can be simplified to

$$
\mathrm{J}_{\mathrm{sed}}=\mathrm{k}\left(\mathrm{C}_{\mathrm{PH}}-\mathrm{C}_{\mathrm{BS}}\right) \mathrm{Z}_{\mathrm{PH}} .
$$

Two seasons were considered: summer (Jun-Aug) and early winter (Nov-Jan). Although water residence times are likely to be longer in the winter compared to the summer (Woodgate et al., 2005a), we use a 3-month residence time for both seasons to avoid extrapolating the available ${ }^{228} \mathrm{Ra}$ data over the late winter-early spring period when no data are available. This time constraint also reduces possible bias from WW inflow from the Bering Sea, which is strongest between January and April (Woodgate et al., 2005a).

The summer Point Hope ${ }^{228}$ Ra average of $(2.1 \pm 1.0) \times 10^{8}$ atoms $\mathrm{m}^{-3}$ was not different than the Bering Strait average $(2.8 \pm 1.9) \times 10^{8}$ atoms $\mathrm{m}^{-3}$, indicating low sediment inputs during this time of year and precluding a flux calculation. This is consistent with the low modeled tracer inputs near Point Hope during the summer. 
It is also possible, though we consider it unlikely, that the low ${ }^{228} \mathrm{Ra}$ concentration is due to an unaccounted for ${ }^{228} \mathrm{Ra}$ sink, such as depletion through coprecipitation with barite or biological uptake during a particularly productive season (Falkner et al., 1991; Moore \& Dymond, 1991; van Beek et al., 2007).

The early winter ${ }^{228} \mathrm{Ra}$ average was $(5.8 \pm 1.0) \times 10^{8}$ atoms $\mathrm{m}^{-3}$, resulting in a sedimentary flux of $(1.7 \pm 1.2) \times 10^{8}$ atoms $\mathrm{m}^{-2} \mathrm{~d}^{-1}$. This value agrees well with the global average sedimentary ${ }^{228} \mathrm{Ra}$ flux of $(1.4 \pm 0.7) \times 10^{8}$ atoms $\mathrm{m}^{-2} \mathrm{~d}^{-1}$ (Moore et al., 2008) and the value reported for the northeast Chukchi shelf, $(1.5 \pm 0.7) \times 10^{8}$ atoms $\mathrm{m}^{-2} \mathrm{~d}^{-1}$ (Vieira et al., 2018). An estimate of the pan-Arctic sedimentary ${ }^{228} \mathrm{Ra}$ flux was determined by Kipp et al. (2018), who assumed that the sources of ${ }^{228}$ Ra to the Arctic surface ocean must be balanced by sinks and found the flux from shelf sediments by difference. The best estimate determined using this method was $1.2 \times 10^{23}$ atoms year $^{-1}$, with a possible range of $7.5 \times 10^{22}-2.5 \times 10^{23}$ atoms year $^{-1}$. Normalizing this flux to the area of Arctic shelves $\left(5 \times 10^{12} \mathrm{~m}^{2}\right.$ (Jakobsson, 2002)) and converting to units of $\mathrm{d}^{-1}$ yields a flux of $6.5 \times 10^{7}$ atoms $\mathrm{m}^{-2} \mathrm{~d}^{-1}$ (possible range of $4.1 \times 10^{7}-1.4 \times 10^{8}$ atoms $\mathrm{m}^{-2} \mathrm{~d}^{-1}$ ). This estimate is slightly lower than the early winter flux from the Chukchi shelf presented here; this may be due to the assumption that the Kipp et al. (2018) flux is uniformly distributed across all of the Arctic shelves and all seasons. Nonetheless, the overlap between these two independently calculated flux values is encouraging.

In order to convert the ${ }^{228} \mathrm{Ra}$ flux to a benthic nutrient flux, the ${ }^{228} \mathrm{Ra}$ flux would be multiplied by the ratio of the porewater gradients of ${ }^{228} \mathrm{Ra}$ and the nutrient of interest. The lack of such porewater or bottom water data (particularly from the winter season) precludes such a calculation here, but if such data are collected through future process studies, they can be used with the flux estimate presented here to constrain benthic nutrient fluxes to the Chukchi Sea.

\section{Implications}

As the addition of sediment-derived materials to the water column is significantly enhanced by water column convection triggered by ice formation and brine rejection, it may be affected by the warming Arctic climate. Changes in the timing of ice formation and breakup, as well as the frequency of polynyas and leads, could impact sediment-water column exchange (Williams \& Carmack, 2015). Increased storm frequency (Ardyna et al., 2014) and enhanced internal wave energy (Rainville \& Woodgate, 2009) may also drive increased fluxes of shelf-derived materials. Because the timing of sea ice retreat must coincide with nutrient availability to create an open-water bloom, shifts in the timing of sea ice breakup may change the relationship between these two limiting factors. The rates of primary production in the southeast Chukchi Sea near Point Hope are highest in June (Grebmeier et al., 2015), coinciding with sea ice retreat (Frey et al., 2015). Here, we have shown that the concentration of a sediment-derived tracer in this region is greatest in the winter (Figure 2a), implying that benthic nutrient fluxes are also enhanced in the winter. Therefore, as ice retreats and removes light limitation earlier in the season, the higher nutrient concentrations available in the spring may support more primary production in this region. The combination of observational and modeling results presented here can serve to improve our understanding of the complex interactions between nutrient, sea ice, and biological cycles in a rapidly changing Arctic.

\section{Acknowledgments}

This study presents data from multiple Arctic expeditions over the past two decades, and we are indebted to the captains, crews, and scientific parties that made this data collection possible. This work was funded by NSF awards OCE-1458305 to M. Charette, OCE-1458424 to W. Moore, OCE-1434085 to D. Kadko, PLR-1504333 to R. Pickart, and OPP-1822334 to M. Spall. Funding was also provided by National Oceanic and Atmospheric Administration Grant NA14-OAR4320158 to R. Pickart. L. Kipp was supported by an Ocean Frontier Institute Postdoctoral Fellowship. Radium data used in this manuscript are available in Table S1.

\section{References}

Anderson, L. G., Björk, G., Holby, O., Jutterström, S., Mörth, C. M., O'Regan, M., et al. (2017). Shelf-Basin interaction along the East Siberian Sea. Ocean Science, 13(2), 349-363. https://doi.org/10.5194/os-13-349-2017

Ardyna, M., Babin, M., Gosselin, M., Devred, E., Rainville, L., \& Tremblay, J.-É. (2014). Recent Arctic Ocean sea ice loss triggers novel fall phytoplankton blooms. Geophysical Research Letters, 41, 6207-6212. https://doi.org/10.1002/2014GL061047

Arrigo, K. R., Mills, M. M., van Dijken, G. L., Lowry, K. E., Pickart, R. S., \& Schlitzer, R. (2017). Late spring nitrate distributions beneath the ice-covered Northeastern Chukchi shelf. Journal of Geophysical Research: Biogeosciences, 122, 2409-2417. https://doi.org/10.1002/ 2017JG003881

Arrigo, K. R., van Dijken, G., \& Pabi, S. (2008). Impact of a shrinking Arctic ice cover on marine primary production. Geophysical Research Letters, 35, L19603. https://doi.org/10.1029/2008GL035028

Brown, K. A., McLaughlin, F., Tortell, P. D., Yamamoto-Kawai, M., \& Francois, R. (2016). Sources of dissolved inorganic carbon to the Canada Basin halocline: A multitracer study. Journal of Geophysical Research: Oceans, 121, 2918-2936. https://doi.org/10.1002/ 2015JC011535

Brown, Z. W., Casciotti, K. L., Pickart, R. S., Swift, J. H., \& Arrigo, K. R. (2015). Aspects of the marine nitrogen cycle of the Chukchi Sea shelf and Canada Basin. Deep-Sea Research Part II: Topical Studies in Oceanography, 118, 73-87. https://doi.org/10.1016/j.dsr2.2015.02.009

Cochand, M., Molson, J., \& Lemieux, J. (2019). Groundwater hydrogeochemistry in permafrost regions. Permafrost and Periglacial Processes, 30(2), 90-103. https://doi.org/10.1002/ppp.1998 
Codispoti, L. A., Flagg, C., Kelly, V., \& Swift, J. H. (2005). Hydrographic conditions during the 2002 SBI process experiments. Deep-Sea Research Part II: Topical Studies in Oceanography, 52, 3199-3226. https://doi.org/10.1016/j.dsr2.2005.10.007

Corlett, W. B., \& Pickart, R. S. (2017). The Chukchi slope current. Progress in Oceanography, 153, 50-65. https://doi.org/10.1016/j. pocean.2017.04.005

Devol, A. H., Codispoti, L. A., \& Christensen, J. P. (1997). Summer and winter denitrification rates in western Arctic shelf sediments. Continental Shelf Research, 17(9), 1029-1033. https://doi.org/10.1016/S0278-4343(97)00003-4

Falkner, K. K., O'Neill, D. J., Todd, J. F., Moore, W. S., \& Edmond, J. M. (1991). Depletion of barium and radium-226 in Black Sea surface waters over the past thirty years. Nature, 350(6318), 491-494. https://doi.org/10.1038/350491a0

Frey, K. E., Moore, G. W. K., Cooper, L. W., \& Grebmeier, J. M. (2015). Divergent patterns of recent sea ice cover across the Bering, Chukchi, and Beaufort seas of the Pacific Arctic region. Progress in Oceanography, 136, 32-49. https://doi.org/10.1016/j. pocean.2015.05.009

Granger, J., Sigman, D. M., Gagnon, J., Tremblay, J.-E., \& Mucci, A. (2018). On the properties of the Arctic halocline and deep water masses of the Canada Basin from nitrate isotope ratios. Journal of Geophysical Research: Oceans, 123, 5443-5458. https://doi.org/10.1029/ 2018JC014110

Grebmeier, J. M., Bluhm, B. A., Cooper, L. W., Danielson, S. L., Arrigo, K. R., Blanchard, A. L., et al. (2015). Ecosystem characteristics and processes facilitating persistent macrobenthic biomass hotspots and associated benthivory in the Pacific Arctic. Progress in Oceanography, 136, 92-114. https://doi.org/10.1016/j.pocean.2015.05.006

Günther, F., Overduin, P. P., Yakshina, I. A., Opel, T., Baranskaya, A. V., \& Grigoriev, M. N. (2015). Observing Muostakh disappear: Permafrost thaw subsidence and erosion of a ground-ice-rich island in response to arctic summer warming and sea ice reduction. The Cryosphere, 9, 151-178. https://doi.org/10.5194/tc-9-151-2015

Henriksen, K., Blackburn, T., Lomstein, B., \& McRoy, C. (1990). Rates of nitrification, distribution of nitrifying bacteria and inorganic N fluxes in northern Bering-Chukchi shelf sediments. Continental Shelf Research, 13(5), 629-651.

Jakobsson, M. (2002). Hypsometry and volume of the Arctic Ocean and its constituent seas. Geochemistry, Geophysics, Geosystems, 3(5). https://doi.org/10.1029/2001GC000302

Jones, B. M., Arp, C. D., Jorgenson, M. T., Hinkel, K. M., Schmutz, J. A., \& Flint, P. L. (2009). Increase in the rate and uniformity of coastline erosion in Arctic Alaska. Geophysical Research Letters, 36, L03503. https://doi.org/10.1029/2008GL036205

Jones, E. P., \& Anderson, L. G. (1986). On the origin of the chemical properties of the Arctic Ocean halocline. Journal of Geophysical Research, 91(C9), 10,759-10,767. https://doi.org/10.1029/JC091iC09p10759

Kadko, D., \& Muench, R. (2005). Evaluation of shelf-basin interaction in the western Arctic by use of short-lived radium isotopes: The importance of mesoscale processes. Deep-Sea Research Part II: Topical Studies in Oceanography, 52(24-26), 3227-3244. https://doi.org/ 10.1016/j.dsr2.2005.10.008

Kadko, D., Pickart, R. S., \& Mathis, J. (2008). Age characteristics of a shelf-break eddy in the western Arctic and implications for shelf-basin exchange. Journal of Geophysical Research, 113, C02018. https://doi.org/10.1029/2007JC004429

Kipp, L. E., Charette, M. A., Moore, W. S., Henderson, P. B., \& Rigor, I. G. (2018). Increased fluxes of shelf-derived materials to the central Arctic Ocean. Science Advances, 4(1). https://doi.org/10.1126/sciadv.aao1302

Kipp, L. E., Henderson, P. B., Wang, Z. A., \& Charette, M. A. (2020). Deltaic and estuarine controls on Mackenzie River solute fluxes to the Arctic Ocean. Estuaries and Coasts. https://doi.org/10.1007/s12237-020-00739-8

Kipp, L. E., Kadko, D. C., Pickart, R. S., Henderson, P. B., Moore, W. S., \& Charette, M. A. (2019). Shelf-basin interactions and water mass residence times in the Western Arctic Ocean: Insights provided by radium isotopes. Journal of Geophysical Research: Oceans, 124, 3279-3297. https://doi.org/10.1029/2019JC014988

Large, W. G., Mcwilliams, J. C., \& Doney, S. C. (1994). Oceanic vertical mixing-A review and a model with a nonlocal boundary-layer parameterization. Reviews of Geophysics, 32(94), 363-403. https://doi.org/10.1029/94rg01872

Li, M., Pickart, R. S., Spall, M. A., Weingartner, T. J., Lin, P., Moore, G. W. K., \& Qi, Y. (2019). Circulation of the Chukchi Sea shelfbreak and slope from moored timeseries. Progress in Oceanography, 172, 14-33. https://doi.org/10.1016/j.pocean.2019.01.002

Lin, P., Pickart, R. S., McRaven, L. T., Arrigo, K. R., Bahr, F., Lowry, K. E., et al. (2019). Water Mass Evolution and Circulation of the Northeastern Chukchi Sea in Summer: Implications for Nutrient Distributions. Journal of Geophysical Research: Oceans, 124, 4416-4432. https://doi.org/10.1029/2019JC015185

Linders, J., Pickart, R. S., Björk, G., \& Moore, G. W. K. (2017). On the nature and origin of water masses in Herald Canyon, Chukchi Sea: Synoptic surveys in summer 2004, 2008, and 2009. Progress in Oceanography, 159, 99-114. https://doi.org/10.1016/j. pocean.2017.09.005

Lowry, K. E., Pickart, R. S., Mills, M. M., Brown, Z. W., van Dijken, G. L., Bates, N. R., \& Arrigo, K. R. (2015). The influence of winter water on phytoplankton blooms in the Chukchi Sea. Deep-Sea Research Part II: Topical Studies in Oceanography, 118, 53-72. https://doi.org/ 10.1016/j.dsr2.2015.06.006

Lowry, K. E., Pickart, R. S., Selz, V., Mills, M. M., Pacini, A., Lewis, K. M., et al. (2018). Under-ice phytoplankton blooms inhibited by spring convective mixing in refreezing leads. Journal of Geophysical Research: Oceans, 123, 90-109. https://doi.org/10.1002/2016JC012575

Marshall, J., Hill, C., Perelman, L., \& Adcroft, A. (1997). Hydrostatic, quasi-hydrostatic, and nonhydrostatic ocean modeling. Journal of Geophysical Research, 102(C3), 5733-5752. https://doi.org/10.1029/96JC02776

Mathis, J. T., Grebmeier, J. M., Hansell, D. A., Hopcroft, R. R., Kirchman, D. L., Lee, S. H., et al. (2014). Carbon biogeochemistry of the Western Arctic: Primary production, carbon export and the controls on ocean acidification. In J. M. Grebmeier, \& W. Maslowski (Eds.), The Pacific Arctic Region: Ecosystem Status and Trends in a Rapidly Changing Environment (pp. 223-268). Dordrecht: Springer Netherlands. https://doi.org/10.1007/978-94-017-8863-2_9

Mathis, J. T., Pickart, R. S., Hansell, D. A., Kadko, D., \& Bates, N. R. (2007). Eddy transport of organic carbon and nutrients from the Chukchi shelf: Impact on the upper halocline of the western Arctic Ocean. Journal of Geophysical Research, 112, C05011. https://doi.org/ $10.1029 / 2006 \mathrm{JC} 003899$

Moore, W. S., \& Dymond, J. (1991). Fluxes of ${ }^{226} \mathrm{Ra}$ and barium in the Pacific Ocean: The importance of boundary processes. Earth and Planetary Science Letters, 107(1), 55-68. https://doi.org/10.1016/0012-821X(91)90043-H

Moore, W. S., Sarmiento, J. L., \& Key, R. M. (2008). Submarine groundwater discharge revealed by ${ }^{228}$ Ra distribution in the upper Atlantic Ocean. Nature Geoscience, 1(5), 309-311. https://doi.org/10.1038/ngeo183

Muench, R. D., Schumacher, J. D., \& Salo, S. A. (1988). Winter currents and hydrographic conditions on the northern central Bering Sea shelf. Journal of Geophysical Research, 93(C1), 516-526. https://doi.org/10.1029/JC093iC01p00516

Nakayama, Y., Fujita, S., Kuma, K., \& Shimada, K. (2011). Iron and humic-type fluorescent dissolved organic matter in the Chukchi Sea and Canada Basin of the western Arctic Ocean. Journal of Geophysical Research, 116, C07031. https://doi.org/10.1029/2010JC006779 
Pacini, A., Moore, G. W. K., Pickart, R. S., Nobre, C., Bahr, F., Våge, K., \& Arrigo, K. R. (2019). Characteristics and transformation of Pacific winter water on the Chukchi Sea shelf in late spring. Journal of Geophysical Research: Oceans, 124, 7153-7177. https://doi.org/10.1029/ 2019JC015261

Pickart, R. S., Moore, G. W. K., Mao, C., Bahr, F., Nobre, C., \& Weingartner, T. J. (2016). Circulation of winter water on the Chukchi shelf in early summer. Deep-Sea Research Part II: Topical Studies in Oceanography, 130, 56-75. https://doi.org/10.1016/j.dsr2.2016.05.001

Pickart, R. S., Weingartner, T. J., Pratt, L. J., Zimmermann, S., \& Torres, D. J. (2005). Flow of winter-transformed Pacific water into the Western Arctic. Deep-Sea Research Part II: Topical Studies in Oceanography, 52(24-26), 3175-3198. https://doi.org/10.1016/j. dsr2.2005.10.009

Rainville, L., \& Woodgate, R. A. (2009). Observations of internal wave generation in the seasonally ice-free Arctic. Geophysical Research Letters, 36, L23604. https://doi.org/10.1029/2009GL041291

Reid, D. F., Key, R. M., \& Schink, D. R. (1979). Radium, thorium, and actinium extraction from seawater using an improved manganese-oxide-coated fiber. Earth and Planetary Science Letters, 43, 223-226. https://doi.org/10.1016/0012-821X(79)90205-X

Rutgers van der Loeff, M., Cai, P., Stimac, I., Bauch, D., Hanfland, C., Roeske, T., \& Moran, S. B. (2012). Shelf-basin exchange times of Arctic surface waters estimated from ${ }^{228} \mathrm{Th} /{ }^{228} \mathrm{Ra}$ disequilibrium. Journal of Geophysical Research, 117, C03024. https://doi.org/10.1029/ 2011JC007478

Rutgers van der Loeff, M., Key, R. M., Scholten, J., Bauch, D., \& Michel, A. (1995). ${ }^{228}$ Ra as a tracer for shelf water in the Arctic Ocean. Deep-Sea Research Part II: Topical Studies in Oceanography, 42(6), 1533-1553.

Rutgers van der Loeff, M., Kipp, L., Charette, M. A., Moore, W. S., Black, E., Stimac, I., et al. (2018). Radium isotopes across the Arctic Ocean show time scales of water mass ventilation and increasing shelf inputs. Journal of Geophysical Research: Oceans, 123, 4853-4873. https://doi.org/10.1029/2018JC013888

Serreze, M. C., Holland, M. M., \& Stroeve, J. (2007). Perspectives on the Arctic's shrinking sea-ice cover. Science, 315(5818), 1533-1536. https://doi.org/10.1126/science.1139426

Spall, M. A. (2007). Circulation and water mass transformation in a model of the Chukchi Sea. Journal of Geophysical Research, 112, C05025. https://doi.org/10.1029/2005JC003364

Spall, M. A., Pickart, R. S., Fratantoni, P. S., \& Plueddemann, A. J. (2008). Western Arctic Shelfbreak eddies: Formation and transport Journal of Physical Oceanography, 38(8), 1644-1668. https://doi.org/10.1175/2007JPO3829.1

Spall, M. A., Pickart, R. S., Li, M., Itoh, M., Lin, P., Kikuchi, T., \& Qi, Y. (2018). Transport of Pacific water into the Canada Basin and the formation of the Chukchi slope current. Journal of Geophysical Research: Oceans, 123, 7453-7471. https://doi.org/10.1029/2018JC013825

Trefry, J. H., Trocine, R. P., Cooper, L. W., \& Dunton, K. H. (2014). Trace metals and organic carbon in sediments of the northeastern Chukchi Sea. Deep-Sea Research Part II: Topical Studies in Oceanography, 102, 18-31. https://doi.org/10.1016/j.dsr2.2013.07.018

van Beek, P., François, R., Conte, M., Reyss, J. L., Souhaut, M., \& Charette, M. (2007). ${ }^{228} \mathrm{Ra} /{ }^{226} \mathrm{Ra}$ and ${ }^{226} \mathrm{Ra} / \mathrm{Ba}$ ratios to track barite formation and transport in the water column. Geochimica et Cosmochimica Acta, 71(1), 71-86. https://doi.org/10.1016/j.gca.2006.07.041

Vieira, L. H., Achterberg, E. P., Scholten, J., Beck, A. J., Liebetrau, V., Mills, M. M., \& Arrigo, K. R. (2018). Benthic fluxes of trace metals in the Chukchi Sea and their transport into the Arctic Ocean. Marine Chemistry, 208, 43-55. https://doi.org/10.1016/j. marchem.2018.11.001

Walvoord, M. A., Voss, C. I., \& Wellman, T. P. (2012). Influence of permafrost distribution on groundwater flow in the context of climate-driven permafrost thaw: Example from Yukon Flats Basin, Alaska, United States. Water Resources Research, 48 , W07524. https://doi.org/10.1029/2011WR011595

Weingartner, T., Aagaard, K., Woodgate, R., Danielson, S., Sasaki, Y., \& Cavalieri, D. (2005). Circulation on the north Central Chukchi Sea shelf. Deep-Sea Research Part II: Topical Studies in Oceanography, 52(24-26), 3150-3174. https://doi.org/10.1016/j.dsr2.2005.10.015

Weingartner, T. J., Cavalieri, D. J., Aagaard, K., \& Sasaki, Y. (1998). Circulation, dense water formation, and outflow on the northeast Chukchi shelf. Journal of Geophysical Research, 103(C4), 7647-7661. https://doi.org/10.1029/98JC00374

Williams, W. J., \& Carmack, E. C. (2015). The “interior" shelves of the Arctic Ocean: Physical oceanographic setting, climatology and effects of sea-ice retreat on cross-shelf exchange. Progress in Oceanography, 139, 24-41. https://doi.org/10.1016/j.pocean.2015.07.008

Woodgate, R. A. (2018). Increases in the Pacific inflow to the Arctic from 1990 to 2015, and insights into seasonal trends and driving mechanisms from year-round Bering Strait mooring data. Progress in Oceanography, 160, 124-154. https://doi.org/10.1016/j. pocean.2017.12.007

Woodgate, R. A., Aagaard, K., \& Weingartner, T. J. (2005a). A year in the physical oceanography of the Chukchi Sea: Moored measurements from autumn 1990-1991. Deep-Sea Research Part II: Topical Studies in Oceanography, 52(24-26), 3116-3149. https://doi.org/ 10.1016/j.dsr2.2005.10.016

Woodgate, R. A., Aagaard, K., \& Weingartner, T. J. (2005b). Monthly temperature, salinity, and transport variability of the Bering Strait through flow. Geophysical Research Letters, 32, L04601. https://doi.org/10.1029/2004GL021880 